\title{
The Analysis and Design of Management System for University Students' Ideological and Political Education
}

\author{
LIU Dai ${ }^{1, a}$ \\ ${ }^{1}$ Ideological and political theory department, Shenyang sport university,110102 \\ a liudai_239@126.com
}

Keywords: Ideological and political education; University Students; Management system

\begin{abstract}
In this paper, the domestic ideological and political education informatization construction have been various researched, it believes the construction of the ideological and political education management objectives should be determined by the "information technology centered" to " the learners as the center", and combining the actual situation, design and develop a set of university students' ideological and political education management system. The system mainly use Microsoft Visual Studio 6.0 as a development tool, using SQL Server2000 as the database storage system, system design mainly includes the content of the ideological and political education, ideological and political propaganda, ideological and political consultation and communication, the ideological and political supervision, and system management module.
\end{abstract}

\section{Introduction}

Since the end of last century, represented by the Internet information technology obtained the swift and violent development, not only to the global economic, political, and cultural life has brought strong impact, but also for in rapid growth, the world outlook and outlook on life has not really formed by college students, network information have also been widely affects their ideology, values, ways of thinking, and all aspects of daily life, to the traditional ideological and political education has brought intense impact. In terms of education effect, along with the network popularization as well as the construction of campus network, the increase in the number of different view and understanding of college students through the network contact, the thought and behavior towards increasingly personalized direction, in this case it is difficult to let it be passively accept the same teacher indoctrinate ideas, teacher's dominant position affected, also make the effect of the ideological and political education.

In terms of education content, with the continuous improvement of our country opening to the outside world and network openness, in its relations with different countries all kinds of different countries and national socialist ideological trend and the concept of constantly hit our traditional ideological and political education content, the socialist core value and other mainstream value dominance affected,. In terms of education method, in the face of increasingly rich network multimedia resources, the traditional classroom primarily, by teachers' educational method of ideological and political education alone appear dull and pale, is difficult to obtain ideal education effect. Therefore, how to fully into the information technology and the ideological and political education, to explore more effective methods of ideological and political education, the ideological and political education will be facing a major issue.

\section{Requirement analysis of the management system}

Due to the particularity of the ideological and political education activities, as an important part of education informatization construction of the ideological and political education information platform construction is not only a technical problem, more is to deal with "people" to the problem of the application of information technology. Therefore, to solve this problem, first of all need to fully read about ideological and political education and literature education informatization and the information, for the requirements analysis to lay the good theories foundation. 
Functional goal of this system is the use of information and network technology, the construction of a highly integrated with other campus network system, connected to the Internet, can be achieved between teachers and students interactive teaching of Ideological and political education, publicity and consultation and communication, monitoring, and the teaching management efficiency, integrated information management platform and other functions, the characteristics of the management system is shown in figure 1. Specifically, through the students' Ideological and political management system has changed the traditional mode of Ideological and political education to teachers, and bidirectional mainly by students, teachers and students "interaction" teaching mode, the original to the classroom teaching as the main space is extended to the entire network, and the use of time network transmission characteristics, enhance the efficiency of Ideological and political education, realization on College Students' ideological, political, moral and psychological of personalized and humane education and guidance of the purpose [2-3].

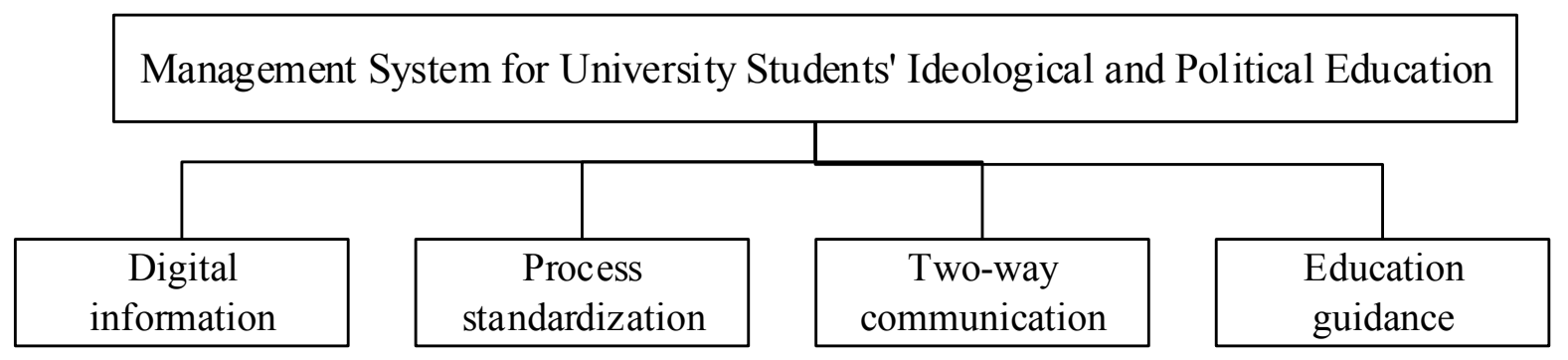

Figure 1.The characteristics of the management system

Digital information. It is related to the ideological and political education of students in the form of information as much as possible digital inductive, sorting, using and sharing, such as students' personal information, teachers' personal information, education information, other school management information etc..

Process standardization. Through the design process and achieve reasonable route of ideological and political education platform, optional sex is big, strong subjective change past teaching process, the establishment of information platform based on Ideological Education mechanism.

Two-way communication. Information technology teachers' and students' education and management and other related departments of the two-way interactive communication mode, enhancing the efficiency of communication and frequent sexual behavior.

Education guidance. Guide the students to determine their own, learn and adapt to the individuality of students, hoping to promote their healthy growth. The computer information technology can make the teaching management personnel to provide accurate computer process instead of the traditional manual operation, the breakthrough time and space limitation, improve the efficiency of management.

\section{System function analysis and composition}

Because the education process general content and method of Ideological and political education work of the diversity and complexity of the relevant personnel according to the working system and the system's overall function, the system is divided into the ideological and political teaching subsystem, structure subsystem function of ideology and political propaganda, ideology and political consultation and communication subsystem and monitoring subsystem of the ideology and political system, as shown in figure 2 .

Ideological and political teaching subsystem. Through the construction of network teaching system, network teaching. According to the teachers and students of different activities, subsystem learning module is divided into Teachers' work and students. Content includes the network teaching, group learning, work management, answer questions and examination.

Ideological and political propaganda subsystem. Ideological politics propaganda should follow the principles and guiding ideology, this is the real information truthfully report the uncertainty information, guidance, promoting information, through the website propaganda and the 
second classroom activities, it can be the network ideological and political education of the rich and colorful penetration to the students..

Ideological and political consultation and communication subsystem. For many college students don't willing to publicly discuss confidentiality topics, such as emotional distress and interpersonal disorder and schizophrenia, sex education, students can in this platform anonymous thought politics full-time teachers or other consulting experts, teachers. In addition, students can also participate in a variety of network community, to discuss topics of common interest to communicate with them.

Supervisory control of ideological and political subsystem. Vigorously promote positive information, at the same time, also through a variety of measures, to prevent the negative influence of information students, try not to directly contact the bad moral information.

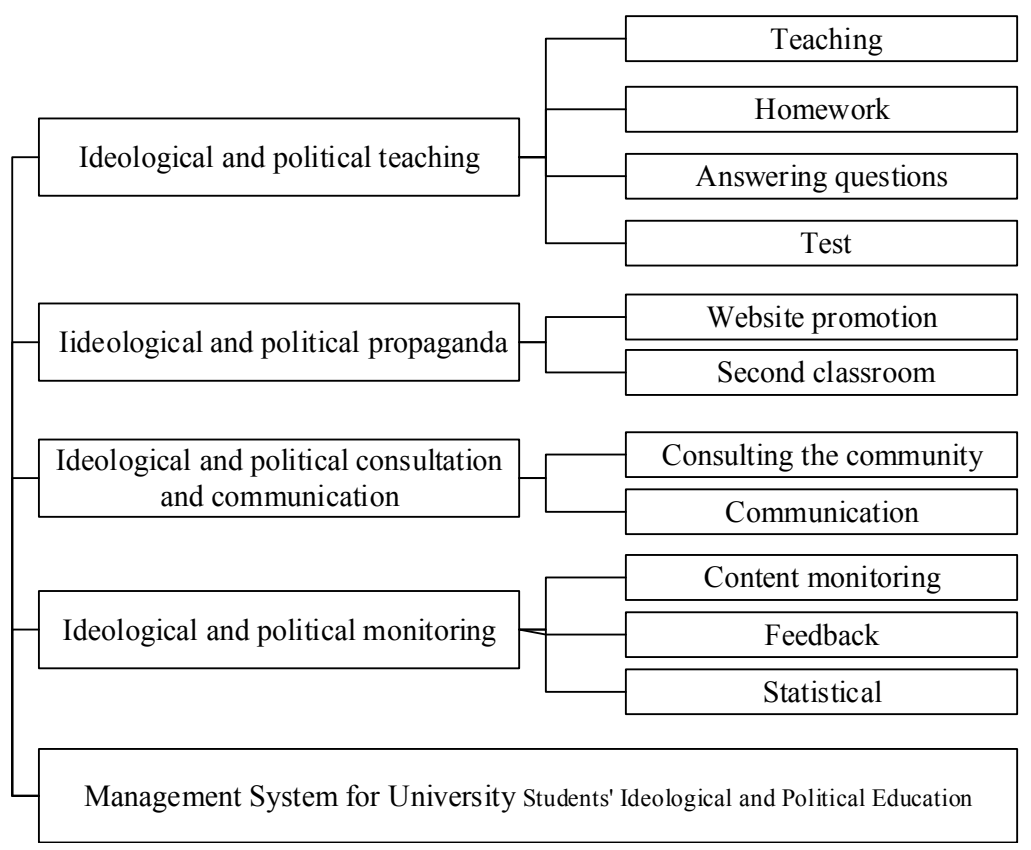

Figure 2. The system function module

\section{System architecture design}

Because the education process general content and method of Ideological and political education work of the diversity and complexity of the relevant personnel according to the working system and the system's overall function, the system is divided into module teaching of ideology and politics, propaganda module, consultation and communication module and monitoring module. Figure 3 is the education and management of technical system architecture diagram. In the figure, the management system of student work, the foundation of the whole system, spring, right, said the main functions of the management system of student work module, can from bottom to top, student job management system is divided into four layers structure.

The construction of College Students' Ideological and political work management system is engaged in Ideological and political education network auxiliary facilities, in addition to the. Net, ASP. Net, ADO. Net, SQLserver2000 enterprise technology, also need to network communication technology integration, network multimedia technology, network programming technology, network technology, virtual reality technology and artificial intelligence technology such as personalized, interactive and practical network platform for ideological and political education, an important factor in overall design to achieve good education results in the overall design. 


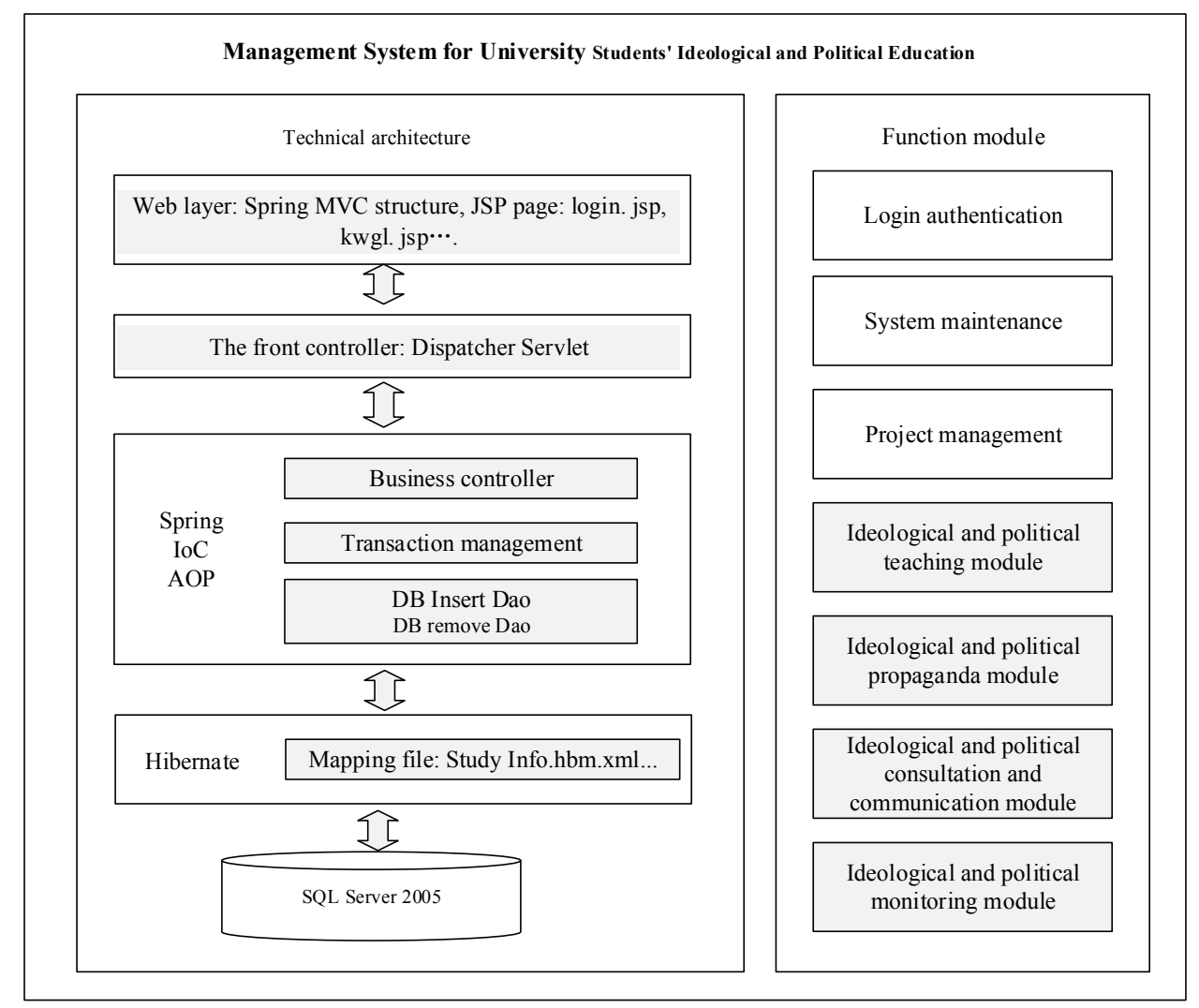

Figure 3. The architecture of the system based on J2EE

\section{Conclusion}

The rapid development of information technology makes the ideological and political education of the current our country by the strong impact, the Internet and university campus network construction and popularization not only brings the new challenges to college education has brought unprecedented opportunities. Ideological and political education informatization is the inevitable developing trend of information age. This article uses the J2EE technology, developed a set of university students' ideological and political education management system. As part of the digital campus construction and teaching system, to enhance the level of students' ideological and political education to lay a good foundation.

\section{References}

[1] C.J. Cooper, S.P. Cooper, D.J. Del: Epidemiologic Perspectives \& Innovations, Vol. 3(2009) No.1, p. 1 .

[2] Z.J. Fan: Computer Science, Vol. 4(2008) No.8, p. 80.

[3] S. HUANG, S. CHEN: Computer Technology and Development, Vol. 2(2010), p. 51.

[4] W. Min: Journal of Convergence Information Technology, Vol. 6(2011) No.1, p. 147.

[5] S.C.W. Kong, H. Li, T.P. Hung: Automation in construction, Vol. 13(2010) No.2, p. 261. 